\title{
Effect of water use efficiency and bentonite levels on growth, yield and chemical composition of seeds for cowpea (Vigna unguiculata,l.) cultivars grown in sandy soil
}

\author{
*Arafa; M.M., ** Darwisch, W.M and **El-Howeity; M.A. \\ * Dep. of Sustainable Development of Environment and Management of its Projects \\ **Dep. of Evaluation of Natural Resources and Planning for their Development
}

Environmental Studies and Research Institute, Univ. of Sadat City, Egypt.

\begin{abstract}
Two field experiments were carried out at the Farm of Environmental Studies and Research Institute, Sadat City University, during the two successive seasons of 2013 and2014,to study the effect of bentonite as soil amendment under three levels of irrigation water on plant growth characteristics as plant height, number of branches, fresh weight per plant, yield and yield component as 100-seed weight, seed yield per plant and total seed yield per feddan and mineral contents of seeds (N,P,K, Fe, Mn and Zn)of three cultivars of cowpea (Vigna unguiculata, L. i.e., Kafr El-Sheikh , Kareem7 and Kareem 14under drip irrigation system. The experiment was conducted under three levels of deficit irrigation levels which were 60,80 , and $100 \%$ of soil moisture content at field capacity) ,bentonite was added to soil before planting at the rate of 0,6 and12ton/fed..Spilt- spilt plots design in a randomized complete blocks with three replicates was used.

Results showed that the application of bentonite as a soil amendment to soil at the highest level (12 ton/fed.) Significantly increased vegetative growth, yield and its components as well as mineral contents of seeds in both seasons compared with the control. As for the effect of irrigation levels, the highest level of irrigation $100 \%$ of soil moisture content at field capacity $\left(4057 \mathrm{~m}^{3} / \mathrm{fed}\right.$.)Significantly increased vegetative growth, yield, yield components and chemical composition of seeds. In addition, cv. Kareem7 recorded the highest values of all tested parameters i.e., vegetative growth, yield and yield components as well as mineral contents of seeds than cvs. Kafr El-Sheikh and Kareem 14in both growing seasons.

The interaction between bentonite amendment and the high irrigation level with cv. Kareem7 significantly increased vegetative growth, yield and its components as well as mineral contents of seeds in both seasons.
\end{abstract}

Key words: Cowpea, Evapotranspiration, bentonite, water use efficiency (WUE ), mineral contents, irrigation levels

Introduction

Cowpea (Vigna unguiculataL.) takes a very important place in world agriculture, with a production potential of about 270 million tons harvested and 12.2 million ha. planted area. Cowpea is one of the main crops in Egypt, where the production is about 4.80 million tons harvested from 0.178 million ha.(FAOstat3, 2013).

It is an annual legume originated in Africa and is now widely grown across the World. It is used as a grain crop, for animal fodder or as a vegetable. The protein in cowpea seed is rich in amino acids (lysine and tryptophan) compared to cereal grains. Therefore, cowpea can be valued as a nutritional supplement to cereals especially in the semi-arid region where cereals are the staple food and there is the menace of nutritional disorders and food insecurity. Africa is in serious need of a protein supplement more than any other region. Fortunately, cowpea tolerates heat and dry conditions and can be grown under both irrigated and non-irrigated conditions. Therefore, cultivation of the crop under irrigation provides an option to intensify its production ( Hussaini et al.2004 ).

Reclamation and land utilization of such soils are faced by several difficulties namely, low organic matter and clay content and loss of add nutrients via leaching or deep percolation together with the yield levels are difficult to attain. Proper management of these soils calls for specialized approaches for sustainable productivity ( Balba, 1999)

Likewise, natural soil conditioners which have been used in Egypt for reclaiming sandy soils are organic manures, composts and bentonite. Bentonite -a rock containing mainly $2: 1$ clay mineral montmorillonite, a member of the semectite family has been recognized in many countries as a good amendment to improve such infertile sandy soil Benkhelifa et al. (2008). Gzaban et al. (2013) found that, the addition of bentonite at rates of 3, 6 and $12 \mathrm{~kg} / \mathrm{m}^{2}$ of soil significantly improved soil structure and increased the amounts of organic matter and total nitrogen in sandy soil. Shalabey et. al. 2005 found that, the application of soil amendments such as chicken manure at rate of $10 \mathrm{~m}^{3} / \mathrm{fed}$., bentonite at rate of $8 \mathrm{ton} / \mathrm{fed}$. and iron ore at rate of $200 \mathrm{Kg} / \mathrm{fed}$. combined with mineral fertilizers at rates of $75 \mathrm{~kg} \mathrm{~N}$, $22 \mathrm{kgP}_{2} \mathrm{O}_{5}$ and $72 \mathrm{kgK}_{2} \mathrm{O} /$ fed. gave significantly the highest vegetative growth components including plant height, number of branches per plant and yield and yield components i.e., 100- seed weight, seed 
yield per plant and per fed. and chemical composition of seeds in both seasons .

Hussaini et al.(2004)found that, irrigation at7, 14 or 21-day by intervals significantly influenced growth components including plant height, number of leaves and number of branches per plant and yield and yield components. The 7-day irrigation interval produced higher shelling percentage in 2002and higher grain yield per plant in 2003 Dadson et al. (2005) studied the effect of water stress on the yield of 10 genetically diverse cowpea genotypes for adaptability to the Delmarva area, the cowpea genotypes were grown in rain-out shelters under non-water-stressed and waterstressed conditions, the results showed that, the harvest index (HI) varied significantly among genotypes, with Texas Cream 8 having the lowest HI.

Aboamera (2010) studied the effect of water stress on the cowpea seed yield under portable sprinkler irrigation system and estimated the effect of water deficit on crop coefficient and water use efficiency. He found that, the highest seed yield (1.12 $\mathrm{Mg} / \mathrm{fed}$.) was observed with fully irrigation with $100 \%$ of field capacity, while the lowest $(0.67$ $\mathrm{Mg} / \mathrm{fed}$.) was with $60 \%$ of field capacity. The lowest value of seed yield was associated with low number of pods/plant (14.6 pods /plant) and small increase in number of seeds per pod (11.00 seeds/pod) and average seed weight (20 g/plant). Moreover, increasing the deficit percent of water application resulted in progressively lower water use efficiency. At $80 \%$ of field capacity, water use efficiency was $0.68 \mathrm{~kg} / \mathrm{m}^{3}$ while, it decreased to $0.59 \mathrm{~kg} / \mathrm{m}^{3}$ as the deficit percent increased from $80 \%$ to $60 \%$ of soil moisture content at field capacity.

Ahmed and Abd El Shakoor(2010.) reported that three contrasting cowpea genotypes i.e. Eien elghazal and two local types ( Zalingei and Elobied) were used and irrigated at 10 days interval and in the stress treatments water was applied at 20 days interval during the vegetative stage, the reproductive stage and both stages .Results showed that, the reproductive stage of development is the most sensitive to water deficit in cowpea, causing a reduction in water-use efficiencies and seed yields of at least $50 \%$ for the three genotypes. In contrast, the genotypes showed a better ability to recover from stress at vegetative stage. The reduction in seed yield was associated with reductions in number of harvested pods per plant, number of seeds per pod and seed size. Abayomi and Abidoye. 2009 and Ichi et al.(2013) indicated that, plant height, number of leaves and flowers per plant of cowpea were increased significantly with decreasing soil moisture stress. However, higher soil moisture stress levels have no appreciable effects on branching, but delayed onset of and time to full flowering. Number of pods and seeds, $\mathrm{HI}$ and shelling percentage as well as grain yield were decreased with increasing soil moisture stress.

Faloye and Alatise (2015) found that, the highest grain yield and biomass yield of 1.06 tons/ha. and 6.95 tons/ha. were observed with fully irrigation(100\%), while the lowest grain yield and biomass yield of 0.71 tons/ha. and 3.48 tons/ha. were observed in the lowest irrigation treatment $(40 \%)$ as a result of moisture availability that contributed to the yield. Therefore, the grain yield and biomass yield were increased progressively with water application.

Cowpea provided sufficient soil $\mathrm{P}$ availability, fix nitrogen to improve soil fertility and cropping system productivity. Additionally, farmers feed cowpea fodder to livestock to increase income, and collect the manure produced for use in their fields. Cowpea thereby reduces farmers' reliance on commercial fertilizers and sustains soil fertility (Odion et al., 2007).

WUE can be affected by meteorological and agronomic factors, and how plant parts involved in WUE are measured. Climatic parameters are responsible for determining evapotranspiration by providing energy for vaporization and removal of water vapor from the leaf and soil surface (Allen $\boldsymbol{e t}$ al., 1998). Within the meteorological factors affecting WUE, the most important are air temperature, air humidity, solar radiation, and wind speed.

WUE values for legume crops usually are lower than cereal crops when grain is the marketable part. Doorenbos and Kassam (1979) reported that WUE ranges for legumes such dry bean ranged from 3 to 6 $\mathrm{kg}$ ha. / $\mathrm{mm}$. for dry pea from 1.5 to $2 \mathrm{~kg}$ ha./ $\mathrm{mm}$., and for soybean from 4 to $7 \mathrm{~kg}$ ha./ $\mathrm{mm}$.

Therefore, the objectives of this study were to investigate the effect of three levels of both irrigation and bentonite on three cultivars of cowpea, vegetative growth characteristics, yield and its components and mineral contents of seeds cultivated under sandy soil conditions.

\section{Materials and Methods}

Two field experiments were carried out during the two summer growing seasons of 2013 and 2014 at the Farm of Environmental Studies and Research, Institute, Sadat City University to study the effect of different irrigation levels (100, 80 and $60 \%$ for ETc ) and three bentonite rate amendments $(0,6$ and 12 ton/ fed. ) as a soil conditioners on three cowpea cultivars(Kafr El-Sheikh, Kareem7 and Kareem 14 ) as well as their interaction on vegetative growth characteristics, yield and its components as well as chemical composition of seeds cultivated under sandy soil conditions .

Mechanical analysis of experimental soil was carried out by means of the pipette method (Piper, 1950), the $\mathrm{pH}$ was measured in a, $1 \mathrm{M} \mathrm{KCI}$ solution, organic matter was determined according the method of Walkley-Black, cation exchange capacity (CEC) was done using ammonium acetate solution; $\mathrm{CaCO} 3$ by means of the calcimeter, all of which methods cited by Black et al. (1965). Contents of (N, P, K, Fe, Mn, Zn and $\mathrm{Cu}$ ) were determined using the methods described 
by Cottenie et al. (1982). The soil of the experimental field was sandy loam in texture. The physical and chemical analysis of soil and bentonite are presented in Table 1 .The recommended agriculture practices for growing cowpea plants were applied whenever required. The experiment included 27 treatments, which were the combination between three levels of irrigations, three additives of bentonite and three cultivars of cowpea. Spilt- spilt plots in a randomized complete blocks design with three replicates was used. The irrigation levels were situated in the main plots, while bentonite in subplots and cultivars in sub- sub plots. The sub-plot area was $13.50 \mathrm{~m}^{2}$ which included 3 rows of $5.0 \mathrm{~m}$ long and $0.9 \mathrm{~m}$ width. Seeds from each cvs. Kafr El-Sheikh, Kareem7 and Kareem 14 were sown on $14^{\text {th }}$ of April in the two investigated seasons of 2013 and 2014 in hills and spaced at $25 \mathrm{~cm}$ apart. Seeds were sown in hills on one side of ridge, then it thinned to leave on plant per hill.

Table 1. Some physical and chemical analyses of the soil and nutrients of bentonite.

\begin{tabular}{|c|c|c|c|c|c|c|c|c|c|c|}
\hline Location of soils & PH(KCI) & $\begin{array}{c}\text { EC } \\
\text { dS. } m^{-1}\end{array}$ & $\underset{\%}{\text { OM }}$ & $\underset{\%}{\mathrm{CaCO}_{3}}$ & \multicolumn{2}{|c|}{$\begin{array}{c}\text { C E C } \\
\text { cmolc. } \\
\text { K g- }^{1}\end{array}$} & $\begin{array}{c}\text { Sand } \\
\%\end{array}$ & $\underset{\%}{\text { Silt }}$ & $\underset{\%}{\text { Clay }}$ & $\begin{array}{l}\text { Texture } \\
\text { Grade }\end{array}$ \\
\hline Sadat City & 7.39 & 1.82 & 0.36 & 5 & 13 & & 72.78 & 19.35 & 7.69 & Sandy loam \\
\hline Materials & $\mathbf{P H}$ & $\begin{array}{c}\text { Total } \\
\text { C \% }\end{array}$ & $\begin{array}{c}\mathbf{N} \\
\text { ppm }\end{array}$ & $\begin{array}{c}\mathbf{P} \\
\mathbf{p p m}\end{array}$ & $\begin{array}{c}\mathbf{K} \\
\mathbf{p p m}\end{array}$ & $\begin{array}{c}\text { Fe } \\
\text { Ppm }\end{array}$ & $\begin{array}{c}\text { Mn } \\
\text { Ppm }\end{array}$ & & & $\begin{array}{c}\mathrm{Cu} \\
\mathbf{p p m}\end{array}$ \\
\hline Bentonite & 8.56 & 0.48 & 0.00 & 14 & 450 & 22 & 11.23 & 9. & & 7.68 \\
\hline Soil (avails, nutr.) & 7.39 & 0.22 & 11.10 & 6.83 & 280 & 14.98 & 3.01 & 1.8 & & 1.01 \\
\hline
\end{tabular}

\section{Irrigation water requirement}

The FAO Penman-Monteith method (Allen et al., 1998) was used to calculate the reference evapotranspiration $\mathrm{ET}_{\mathrm{o}}$ in the CROPWAT Program. Crop water requirements $\left(\mathrm{ET}_{\mathrm{c}}\right)$ over the growing season were determined from $\mathrm{ET}_{\mathrm{o}}$ according to the following equation using crop coefficient $\mathrm{K}_{\mathrm{c}}$ :

$E T_{c}=K_{c} . E T_{o}$ where $\mathrm{ET}_{\mathrm{c}}$ the crop water requirement, $\mathrm{Kc}$ is the crop coefficient and $\mathrm{ET}_{\mathrm{o}}$ is the reference evapotranspiration. Since there was no rainfall during the experimental period, net irrigation requirement was taken to be equal to $\mathrm{ET}_{\mathrm{c}}$.

The total amounts of irrigation water applied (from sowing to harvest) in the irrigation levels in this study were $\left(3808\right.$ and $4057 \mathrm{~m}^{3} / \mathrm{fed}$ in $\mathrm{ET}_{3}, 3047$ and 3246 $\mathrm{m}^{3} /$ fed. in $\mathrm{ET}_{2}$ and 2285 and 2434 in $\mathrm{ET}_{1}$ during studied seasons 2013 and 2014 respectively. The water requirement was determined for different months based on crop growth stages and climatic data.

\section{Water use efficiencies}

Water use efficiency $\left(\mathrm{kg} / \mathrm{m}^{3}\right)$ was calculated as the ratio between total fresh yield at harvest $(\mathrm{kg} / \mathrm{ha}$.) and total water used $\left(\mathrm{m}^{3} / \mathrm{ha}\right.$.).

At harvest ten plants were randomly taken to determine plant height, number of branches / plant, fresh weight / plant, 100- seed weight, seed yield / plant and total yield / fed.
All recorded data were subjected to ANOVA to identify significant treatments and/or interaction effects by ' $F$ test' using the SAS program (SAS Systems for Windows, release 9.2, SAS Institute, Cary, NC, SAS, 2003). Mean separation between the significant treatments was calculated by L.S.D.

\section{Results and Discussion}

\section{I- Vegetative growth:}

Concerning the influence of irrigation levels on vegetative growth, data in Table 2 show that, all the studied vegetative growth parameters i.e., plant height, number of branches and fresh weight/plant were significantly increased with using the highest level of irrigation applied during both growing seasons. In this respect, the highest values in all the studied growth parameters were recorded in case of using the high level of irrigation water (3808 and 4057 $\mathrm{m}^{3} /$ fed.) during 2013 and 2014 seasons respectively. In this regard, the increasing effect of irrigation on vegetative growth of plant may be due to the main role of used water on cells division and cell elongation as well as the physiological function of the cells which consequently affect plant growth. These results are in agreement with those reported by Hussaini et al.(2004) Abayomi and Abidoye ( 2009 ) and Ichi $e t$ al.(2013)on cowpea, indicated that, plant height, numbers of leaves and flowers per plant were 
significantly increased with decreasing soil moisture stress. However, higher soil moisture stress levels have no appreciable effects on branching.

Data presented in Table, 2 show that, all measured parameters of vegetative growth were tended to increase by adding bentoniteup to the highest level (12 ton / fed.) but such increase did not reach the level of significance during both seasons of study .

Table 2. Effect of irrigation, bentonite and cultivars and their first degree of interaction on some vegetative growth characteristics of cowpea plant during the two seasons of study.

\begin{tabular}{|c|c|c|c|c|c|c|c|}
\hline \multicolumn{2}{|c|}{ Seasons } & \multicolumn{3}{|c|}{2013} & \multicolumn{3}{|c|}{2014} \\
\hline Characteristics & Treatments & $\begin{array}{l}\text { Plant height } \\
\text { (cm) }\end{array}$ & $\begin{array}{l}\text { No. of } \\
\text { branches / } \\
\text { plant }\end{array}$ & $\begin{array}{c}\text { Fresh } \\
\text { weight / } \\
\text { plant } \\
\text { (g) }\end{array}$ & $\begin{array}{l}\text { Plant } \\
\text { height } \\
(\mathrm{cm})\end{array}$ & $\begin{array}{c}\text { No. of } \\
\text { branches / } \\
\text { plant }\end{array}$ & $\begin{array}{c}\text { Fresh } \\
\text { weight/ } \\
\text { plant } \\
\text { (g) }\end{array}$ \\
\hline \multirow{4}{*}{. } & Levell & 76.07 & 2.77 & 215.96 & 80.73 & 3.16 & 224.29 \\
\hline & Level 2 & 76.62 & 3.11 & 235.22 & 81.93 & 3.43 & 246.88 \\
\hline & Level 3 & 76.85 & 3.96 & 348.19 & 86.89 & 4.06 & 358.18 \\
\hline & L.S.D. at $0.05 \%$ & n.s. & 0.22 & 4.91 & 0.52 & 0.26 & 3.81 \\
\hline \multirow{4}{*}{ 苋 } & Levell & 73.59 & 3.03 & 230.59 & 76.66 & 3.33 & 253.59 \\
\hline & Level 2 & 74.81 & 3.25 & 270.18 & 76.81 & 3.22 & 280.18 \\
\hline & Level 3 & 75.14 & 3.55 & 298.59 & 77.14 & 3.65 & 309.92 \\
\hline & L.S.D. at $0.05 \%$ & n.s & $\mathrm{n} . \mathrm{s}$ & $\mathrm{n} . \mathrm{s}$ & n.s & n.s & n.s \\
\hline \multirow{4}{*}{ 莺 } & Kareem 14 & 70.12 & 2.96 & 231.15 & 75.66 & 3.18 & 245.81 \\
\hline & Kareem 7 & 80.92 & 3.64 & 311.16 & 85.68 & 3.84 & 321.16 \\
\hline & Kafr El-sheikh & 72.50 & 3.24 & 257.05 & 78.34 & 3.41 & 269.55 \\
\hline & L.S.D. at $0.05 \%$ & n.s & $\mathrm{n} . \mathrm{s}$ & $\mathrm{n} . \mathrm{s}$ & $\mathrm{n} . \mathrm{s}$ & n.s & $\mathrm{n} . \mathrm{s}$ \\
\hline \multirow{4}{*}{ Bentonite 1} & Kareem 14 & 66.00 & 2.22 & 181.11 & 70.22 & 3.00 & 220.11 \\
\hline & Kareem 7 & 78.11 & 3.77 & 286.33 & 80.11 & 3.77 & 296.33 \\
\hline & Kafr El-sheikh & 76.66 & 3.11 & 224.33 & 79.66 & 3.22 & 244.33 \\
\hline & Kareem 14 & 72.44 & 3.22 & 258.33 & 74.44 & 3.11 & 268.33 \\
\hline \multirow[t]{2}{*}{ Bentonite 2} & Kareem 7 & 78.66 & 3.33 & 287.77 & 80.66 & 3.33 & 297.77 \\
\hline & Kafr El-sheikh & 73.33 & 3.22 & 264.44 & 75.33 & 3.22 & 274.44 \\
\hline \multirow{4}{*}{ Bentonite 3} & Kareem 14 & 76.66 & 3.44 & 252.66 & 78.66 & 3.33 & 265.66 \\
\hline & Kareem 7 & 82.66 & 3.77 & 387.77 & 85.66 & 3.99 & 398.77 \\
\hline & Kafr El-sheikh & 66.11 & 3.44 & 255.33 & 67.11 & 3.65 & 265.33 \\
\hline & L.S.D. at $0.05 \%$ & 10.26 & n.s & 68.42 & 9.36 & n.s & 60.20 \\
\hline \multirow{3}{*}{ Irrigation 1} & Kareem 14 & 62.44 & 2.11 & 196.00 & 72.44 & 2.66 & 200.00 \\
\hline & Kareem 7 & 83.88 & 3.55 & 240.22 & 89.88 & 3.85 & 250.22 \\
\hline & Kafr El-sheikh & 63.88 & 2.66 & 211.66 & 79.88 & 2.99 & 222.66 \\
\hline \multirow{3}{*}{ Irrigation 2} & Kareem 14 & 70.44 & 2.88 & 193.55 & 75.64 & 3.00 & 205.55 \\
\hline & Kareem 7 & 80.00 & 3.33 & 276.00 & 85.50 & 3.88 & 285.00 \\
\hline & Kafr El-sheikh & 79.44 & 3.11 & 236.11 & 82.44 & 3.42 & 250.11 \\
\hline \multirow{4}{*}{ Irrigation 3} & Kareem 14 & 72.77 & 3.88 & 305.22 & 82.77 & 3.98 & 315.22 \\
\hline & Kareem 7 & 82.22 & 4.11 & 388.88 & 92.25 & 4.21 & 398.88 \\
\hline & Kafr El-sheikh & 75.55 & 3.88 & 350.44 & 85.65 & 3.98 & 360.44 \\
\hline & L.S.D. at $0.05 \%$ & 9.44 & 1.99 & 76.35 & 8.40 & 1.09 & 66.35 \\
\hline \multirow{3}{*}{ Bentonite 1} & Irrigation 1 & 66.33 & 2.22 & 229.44 & 76.33 & 2.75 & 240.44 \\
\hline & Irrigation 2 & 73.66 & 3.44 & 233.33 & 83.66 & 3.75 & 243.33 \\
\hline & Irrigation 3 & 84.44 & 4.11 & 347.77 & 94.44 & 4.66 & 357.77 \\
\hline \multirow{3}{*}{ Bentonite 2} & Irrigation 1 Irrigation & 72.77 & 2.11 & 150.22 & 78.77 & 2.66 & 160.22 \\
\hline & 2 & 72.77 & 3.44 & 222.88 & 82.77 & 3.64 & 232.88 \\
\hline & Irrigation 3 & 79.88 & 3.55 & 318.66 & 89.88 & 3.75 & 328.66 \\
\hline \multirow{4}{*}{ Bentonite 3} & Irrigation 1 & 71.11 & 2.55 & 195.55 & 81.11 & 2.75 & 205.55 \\
\hline & Irrigation 2 & 72.66 & 3.77 & 322.11 & 82.66 & 3.99 & 350.11 \\
\hline & Irrigation 3 & 77.00 & 4.33 & 378.11 & 87.00 & 4.65 & 399.11 \\
\hline & L.S.D. at $0.05 \%$ & 10.23 & 0.75 & 70.01 & 9.33 & 0.65 & 60.01 \\
\hline
\end{tabular}


In this respect, Shalabey et al. (2005) found that, application of soil conditioners amendments such as chicken manure at rate of $10 \mathrm{~m}^{3} / \mathrm{fed}$., bentonite at rate 8 ton / fed. and iron ore at rate of $200 \mathrm{Kg} / \mathrm{fad}$. combined with mineral fertilizers at rates $75 \mathrm{~kg} \mathrm{~N}$, $22 \mathrm{~kg} \quad \mathrm{P}_{2} \mathrm{O}_{5}$ and $72 \mathrm{kgK}_{2} \mathrm{O} /$ fed. gave the highest vegetative growth components including plant height, number of branches per plant.

With regard, to the effect of cultivars results in Table2 reveal that, there were significant differences in all parameters of vegetative growth. The highest values were recorded in case of cv. Kareem7 compared with cvs. Kafr El-Sheikh and Kareem 14. Such results were true during both seasons of study. Such deference between cultivars might be due to the variation in genetic pool between the cowpea cultivars. Similar results were reported by Ahmed and Abd El Shakoor (2010).

As for the interaction among soil amendment levels, irrigation levels and cultivars on vegetative growth and its attributes, results show in Table 2 that the highest values were obtained when using the highest level of irrigation plus bentonite with $\mathrm{cv}$. Kareem7. These results are in agreement with these reported by Hussaini et al.(2004) and Shalabey et al. (2005)on cowpea.

\section{2- Yield and its components:-}

Data in Table 3 reveal that, the produced yield and its components, i.e. 100-seed weight, seed yield per plant and total yield per fed. were significantly increased with the highest level of irrigation water in both seasons. In this respect, the highest values in all the studied yield parameters were recorded in case of using the high level of irrigation (3808 and $4057 \mathrm{~m}^{3} /$ fed.) during seasons 2013 and 2014 respectively. The response of yield and its components that attributes to irrigation levels under this condition may be due to that irrigation water increased the availability and uptake of $\mathrm{N}, \mathrm{P}$ and $\mathrm{K}$ by plants in this soil (Table, 1) which positively effect on vegetative growth parameter (Table, 2 ) and resulted in increasing the yield and accumulation of stored food in seeds. These results are agreeable with those reported byAboamera (2010) and Faloye and Alatise (2015) on cowpea.

The same data in Table 3 show that, all parameters of yield and its components were increased but not significant with adding bentonite, this was true during both seasons. These results are in agreement with those reported with Shalabey et al. (2005).
The same in Table 3 show that cv. Kareem7 significantly increased yield and its components than the two cvs. , such results are true during both seasons of study. Such finding are confirmed with those reported by Dadson et al. (2005) and Ahmed and Abdel Shakoor (2010).

Data presented in Table, 3 show that, the effect of the interaction between soil amendment and irrigation levels on yield and its components of cvs. Kafr ElSheikh, Kareem7 and Kareem 14 , such data indicate that the highest levels of irrigation and bentonite with cv. Kareem7 gave the highest values of all yield parameters, this is true during both seasons of 2013 and 2014. Such results are in a good harmony with those reported by Dadson et al. (2005) and Faloye and Alatise (2015) on cowpea.

\section{3- Mineral content of seeds:-}

Data presented in Tables $4 \& 5$ reveal that, the mineral content of seeds i.e., N, K, Fe and Mn were significantly increased with using the highest level of irrigation( 3808 and $4057 \mathrm{~m}^{3} / \mathrm{fed}$.) while $\mathrm{P}$ and $\mathrm{Zn}$ were increased with first and second levels of irrigation during seasons 2013 and 2014 respectively. These results are in agreement with those reported by Dadson et al. (2005).

The same data in Tables, $4 \& 5$ indicate that, adding the highest used level of bentonite (12 ton / fed.) increased the mineral content of seeds without significant difference compared with other tested levels. This is true during the both seasons. These results are in agreement with those reported by Shalabey et al. (2005).

Data in Tables $4 \& 5$ also indicate that, mineral content of seeds was significantly affected by the used cultivars. It is evident that cv. Kafr El-sheikh recorded the highest values than other two cultivars, in both growing seasons. These results are in same line with those reported by Ahmed and Abd El Shakoor (2010).

It could be concluded from Tables $4 \& 5$ that adding bentonite combined with the highest levels of irrigation gave the high concentration of macro and micronutrients of seeds, the positive effect of adding soil amendment to the soil, which would increase available nutrients content in soil. El-sisi (1996) and Odion et al. (2007) on cowpea concluded that, adding the tafla in combination with either organic materials or mineral fertilization to sandy soil achieved the highest positive effect on growth, yield and nutrient uptake in plant as well as increasing available nutrients in soil. 
Table 3. Effect of irrigation, bentonite and cultivars and their interaction on yield and its component of cowpea plant during the two seasons of study.

\begin{tabular}{|c|c|c|c|c|c|c|c|}
\hline \multicolumn{2}{|c|}{ Seasons } & \multicolumn{3}{|c|}{2013} & \multicolumn{3}{|c|}{2014} \\
\hline \multicolumn{2}{|c|}{ Characteristics } & $\begin{array}{l}\text { Weight of } \\
100 \text { seeds } \\
\text { (g) }\end{array}$ & $\begin{array}{l}\text { Seed Yield/ } \\
\text { plant } \\
\text { (g) }\end{array}$ & $\begin{array}{c}\text { Total } \\
\text { yield/Fed. } \\
(\mathrm{Kg})\end{array}$ & $\begin{array}{l}\text { Weight of } 100 \\
\text { seeds } \\
\text { (g) }\end{array}$ & $\begin{array}{l}\text { Seed Yield/ } \\
\text { plant } \\
\text { (g) }\end{array}$ & $\begin{array}{c}\text { Total } \\
\text { yield/Fed. } \\
(\mathrm{Kg})\end{array}$ \\
\hline \multirow{4}{*}{. } & Level1 & 15.82 & 16.42 & 633.14 & 17.07 & 17.42 & 653.14 \\
\hline & Level 2 & 16.61 & 19.85 & 764.22 & 17.61 & 20.92 & 787.65 \\
\hline & Level 3 & 16.86 & 26.88 & 1015.03 & 18.52 & 27.88 & 1084.09 \\
\hline & L.S.D. at $0.05 \%$ & 0.08 & 1.05 & 4.93 & 0.06 & 1.00 & 4.03 \\
\hline \multirow{5}{*}{ 总 } & Level1 & 15.95 & 18.00 & 697.22 & 17.19 & 19.13 & 717.22 \\
\hline & Level 2 & 16.65 & 20.66 & 801.11 & 17.70 & 21.60 & 822.91 \\
\hline & Level 3 & 16.69 & 23.83 & 914.07 & 17.92 & 25.03 & 928.07 \\
\hline & L.S.D. at $0.05 \%$ & n.s & n.s & n.s & n.s & n.s & n.s \\
\hline & Kareem 14 & 16.36 & 20.65 & 799.47 & 17.36 & 21.73 & 818.86 \\
\hline \multirow{2}{*}{ 莣 } & Kareem 7 & 16.57 & 22.47 & 858.92 & 17.83 & 23.47 & 894.67 \\
\hline & Kafr El-sheikh & 16.36 & 19.70 & 754.50 & 17.82 & 20.79 & 783.01 \\
\hline \multirow{5}{*}{ Bentonite 1} & L.S.D. at $0.05 \%$ & n.s & n.s & n.s & n.s & n.s & n.s \\
\hline & Kareem 14 & 14.07 & 16.82 & 660.44 & 15.55 & 17.92 & 680.44 \\
\hline & Kareem 7 & 17.39 & 20.67 & 793.00 & 18.44 & 21.67 & 813.00 \\
\hline & Kafr El-sheikh & 16.39 & 16.52 & 638.22 & 17.59 & 17.82 & 658.22 \\
\hline & Kareem 14 & 16.94 & 20.78 & 807.33 & 17.94 & 21.88 & 827.55 \\
\hline \multirow[t]{2}{*}{ Bentonite 2} & Kareem 7 & 17.58 & 22.98 & 901.55 & 18.66 & 23.68 & 920.75 \\
\hline & Kafr El-sheikh & 15.42 & 18.21 & 694.44 & 16.50 & 19.25 & 720.44 \\
\hline \multirow{4}{*}{ Bentonite 3} & Kareem 14 & 15.27 & 22.76 & 883.55 & 16.57 & 23.96 & 903.55 \\
\hline & Kareem 7 & 17.55 & 26.17 & 990.33 & 18.65 & 27.37 & 995.33 \\
\hline & Kafr El-sheikh & 17.26 & 22.57 & 868.33 & 18.56 & 23.77 & 885.33 \\
\hline & L.S.D. at $0.05 \%$ & 1.11 & 2.86 & 140.82 & 1.00 & 2.22 & 120.22 \\
\hline \multirow{4}{*}{ Irrigation 1} & Kareem 14 & 16.73 & 14.75 & 581.8 & 17.93 & 15.75 & 591.88 \\
\hline & $\begin{array}{l}\text { Kareem } 14 \\
\text { Kareem } 7\end{array}$ & 15.20 & 16.11 & 609.11 & 16.55 & 17.11 & 629.11 \\
\hline & $\begin{array}{l}\text { Kareem } 7 \\
\text { Kafr Fl_sheikh }\end{array}$ & 15.54 & 18.40 & & 16.74 & 19.40 & \\
\hline & & & & 708.44 & & & 738.44 \\
\hline \multirow{3}{*}{ Irrigation 2} & Kareem 14 & 16.99 & 18.81 & 738.88 & 16.99 & 19.91 & 758.98 \\
\hline & Kareem 7 & 16.01 & 22.53 & 863.66 & 17.01 & 23.63 & 893.86 \\
\hline & Kafr El-sheikh & 16.83 & 18.22 & 690.11 & 18.83 & 19.22 & 710.11 \\
\hline \multirow{4}{*}{ Irrigation 3} & Kareem 14 & 18.16 & 30.00 & 1124.77 & 19.16 & 31.00 & 1150.77 \\
\hline & Kareem 7 & 15.71 & 26.37 & 995.88 & 17.71 & 27.37 & 1115.98 \\
\hline & Kafr El-sheikh & 16.7 & 24.28 & 924.44 & 18.70 & 25.28 & 985.54 \\
\hline & L.S.D. at $0.05 \%$ & 1.40 & 2.85 & 140.35 & 1.22 & 2.25 & 110.35 \\
\hline \multirow{4}{*}{ Bentonite 1} & Irrigation 1 & 15.60 & 16.57 & 642.55 & 16.65 & 17.57 & 662.65 \\
\hline & Irrigation 2 & 16.12 & 16.88 & 664.33 & 17.15 & 17.88 & 685.55 \\
\hline & Irrigation 3 & 16.13 & 20.55 & 784.77 & 17.15 & 21.55 & 804.85 \\
\hline & Irrigation 1 & 15.40 & 16.15 & 612.88 & 16.40 & 17.15 & 632.90 \\
\hline \multirow[t]{2}{*}{ Bentonite 2} & Irrigation 2 & 16.80 & 16.35 & 630.11 & 17.80 & 17.35 & 650.81 \\
\hline & Irrigation 3 & 17.75 & 30.47 & 1160.33 & 18.75 & 29.47 & 1180.53 \\
\hline \multirow{4}{*}{ Bentonite 3} & Irrigation 1 & 16.46 & 16.34 & 626.77 & 17.45 & 17.39 & 650.88 \\
\hline & Irrigation 2 & 16.71 & 26.53 & 1015.44 & 17.91 & 27.55 & 1040.55 \\
\hline & Irrigation 3 & 16.91 & 28.64 & 1100.00 & 18.91 & 29.68 & 1125.00 \\
\hline & L.S.D. at $0.05 \%$ & 1.38 & 2.46 & 110.71 & 1.18 & 2.06 & 108.50 \\
\hline
\end{tabular}


Table 4. Effect of irrigation; bentonite and cultivars and their interaction on N,P and K content of seeds during the two seasons of study.

\begin{tabular}{|c|c|c|c|c|c|c|c|}
\hline \multicolumn{2}{|c|}{ Seasons } & \multicolumn{3}{|c|}{2013} & \multicolumn{3}{|c|}{2014} \\
\hline Treatments & Characteristics & $\begin{array}{l}\mathrm{N} \\
\%\end{array}$ & $\begin{array}{l}\mathrm{P} \\
\%\end{array}$ & $\begin{array}{c}\mathrm{K} \\
(\mathrm{ppm})\end{array}$ & $\begin{array}{l}\mathrm{N} \\
\%\end{array}$ & $\begin{array}{l}\mathrm{P} \\
\%\end{array}$ & $\begin{array}{l}\mathrm{K} \\
\text { (ppm) }\end{array}$ \\
\hline . & $\begin{array}{l}\text { Level1 } \\
\text { Level } 2 \\
\text { Level } 3 \\
\text { L.S.D. at } 0.05 \%\end{array}$ & $\begin{array}{l}3.53 \\
4.06 \\
4.15 \\
\text { n.s }\end{array}$ & $\begin{array}{l}0.565 \\
0.491 \\
0.510 \\
0.05\end{array}$ & $\begin{array}{l}24.13 \\
27.55 \\
24.92 \\
\text { n.s }\end{array}$ & $\begin{array}{l}3.73 \\
4.26 \\
4.35 \\
\text { n.s }\end{array}$ & $\begin{array}{l}0.585 \\
0.501 \\
0.530 \\
0.07\end{array}$ & $\begin{array}{l}24.38 \\
27.59 \\
24.90 \\
\text { n.s }\end{array}$ \\
\hline 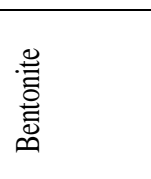 & $\begin{array}{l}\text { Level1 } \\
\text { Level } 2 \\
\text { Level } 3 \\
\text { L.S.D. at } 0.05 \%\end{array}$ & $\begin{array}{l}3.83 \\
3.98 \\
3.93 \\
\text { n.s }\end{array}$ & $\begin{array}{l}0.520 \\
0.503 \\
0.542 \\
\text { n.s }\end{array}$ & $\begin{array}{l}25.55 \\
25.35 \\
25.71 \\
\text { n.s }\end{array}$ & $\begin{array}{l}3.73 \\
3.88 \\
4.03 \\
\text { n.s }\end{array}$ & $\begin{array}{l}0.540 \\
0.533 \\
0.562 \\
\text { n.s }\end{array}$ & $\begin{array}{l}25.53 \\
25.66 \\
25.69 \\
\text { n.s }\end{array}$ \\
\hline 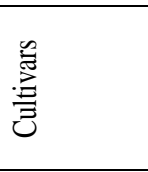 & $\begin{array}{l}\text { Kareem } 14 \\
\text { Kareem } 7 \\
\text { Kafr El-sheikh } \\
\text { L.S.D. at } 0.05 \%\end{array}$ & $\begin{array}{l}3.86 \\
3.87 \\
4.01 \\
\text { n.s } \\
\end{array}$ & $\begin{array}{l}0.483 \\
0.545 \\
0.53 \\
\text { n.s } \\
\end{array}$ & $\begin{array}{l}26.05 \\
23.66 \\
26.90 \\
\text { n.s } \\
\end{array}$ & $\begin{array}{l}3.96 \\
3.97 \\
4.21 \\
\text { n.s } \\
\end{array}$ & $\begin{array}{l}0.493 \\
0.555 \\
0.547 \\
\text { n.s } \\
\end{array}$ & $\begin{array}{l}26.37 \\
23.64 \\
26.88 \\
\text { n.s } \\
\end{array}$ \\
\hline Bentonite 1 & $\begin{array}{l}\text { Kareem } 14 \\
\text { Kareem } 7 \\
\text { Kafr El-sheikh }\end{array}$ & $\begin{array}{l}3.79 \\
3.70 \\
4.00 \\
\end{array}$ & $\begin{array}{l}0.473 \\
0.586 \\
0.501 \\
\end{array}$ & $\begin{array}{l}25.23 \\
22.59 \\
28.83 \\
\end{array}$ & $\begin{array}{l}3.89 \\
3.85 \\
4.20 \\
\end{array}$ & $\begin{array}{l}0.483 \\
0.596 \\
0.521 \\
\end{array}$ & $\begin{array}{l}25.21 \\
22.58 \\
28.81 \\
\end{array}$ \\
\hline Bentonite 2 & $\begin{array}{l}\text { Kareem } 14 \\
\text { Kareem } 7 \\
\text { Kafr El-sheikh }\end{array}$ & $\begin{array}{l}3.98 \\
3.95 \\
3.99 \\
\end{array}$ & $\begin{array}{l}0.438 \\
0.486 \\
0.586 \\
\end{array}$ & $\begin{array}{l}26.17 \\
23.01 \\
26.86 \\
\end{array}$ & $\begin{array}{l}4.08 \\
4.75 \\
4.99 \\
\end{array}$ & $\begin{array}{l}0.458 \\
0.496 \\
0.595 \\
\end{array}$ & $\begin{array}{l}27.16 \\
22.97 \\
26.84 \\
\end{array}$ \\
\hline Bentonite 3 & $\begin{array}{l}\text { Kareem } 14 \\
\text { Kareem } 7 \\
\text { Kafr El-sheikh } \\
\text { L.S.D. at } 0.05 \%\end{array}$ & $\begin{array}{l}3.82 \\
3.96 \\
4.03 \\
\text { n.s }\end{array}$ & $\begin{array}{l}0.540 \\
0.561 \\
0.525 \\
0.10\end{array}$ & $\begin{array}{l}26.74 \\
25.38 \\
25.00 \\
\text { n.s }\end{array}$ & $\begin{array}{l}3.92 \\
4.06 \\
4.23 \\
\text { n.s }\end{array}$ & $\begin{array}{l}0.560 \\
0.581 \\
0.545 \\
0.14\end{array}$ & $\begin{array}{l}26.72 \\
25.36 \\
24.98 \\
\text { n.s }\end{array}$ \\
\hline Irrigation 1 & $\begin{array}{l}\text { Kareem } 14 \\
\text { Kareem } 7 \\
\text { Kafr El-sheikh }\end{array}$ & $\begin{array}{l}3.36 \\
3.54 \\
3.69 \\
\end{array}$ & $\begin{array}{l}0.580 \\
0.603 \\
0.513 \\
\end{array}$ & $\begin{array}{l}24.91 \\
21.14 \\
26.33 \\
\end{array}$ & $\begin{array}{l}3.46 \\
3.64 \\
3.89 \\
\end{array}$ & $\begin{array}{l}0.590 \\
0.623 \\
0.533\end{array}$ & $\begin{array}{l}25.72 \\
21.13 \\
26.31 \\
\end{array}$ \\
\hline Irrigation 2 & $\begin{array}{l}\text { Kareem } 14 \\
\text { Kareem } 7 \\
\text { Kafr El-sheikh }\end{array}$ & $\begin{array}{l}3.54 \\
4.06 \\
4.59\end{array}$ & $\begin{array}{l}0.440 \\
0.518 \\
0.515\end{array}$ & $\begin{array}{l}29.03 \\
26.04 \\
27.60\end{array}$ & $\begin{array}{l}3.74 \\
4.26 \\
4.89\end{array}$ & $\begin{array}{l}0.450 \\
0.538 \\
0.525\end{array}$ & $\begin{array}{l}29.17 \\
26.02 \\
27.58\end{array}$ \\
\hline Irrigation 3 & $\begin{array}{l}\text { Kareem } 14 \\
\text { Kareem } 7 \\
\text { Kafr El-sheikh } \\
\text { L.S.D. at } 0.05 \%\end{array}$ & $\begin{array}{l}4.69 \\
4.02 \\
3.75 \\
1.19\end{array}$ & $\begin{array}{l}0.431 \\
0.513 \\
0.585 \\
0.10\end{array}$ & $\begin{array}{l}24.21 \\
23.80 \\
26.76 \\
6.49\end{array}$ & $\begin{array}{l}4.89 \\
4.22 \\
3.95 \\
1.29\end{array}$ & $\begin{array}{l}0.451 \\
0.533 \\
0.595 \\
0.13\end{array}$ & $\begin{array}{l}24.20 \\
23.77 \\
26.74 \\
6.51 \\
\end{array}$ \\
\hline Bentonite 1 & $\begin{array}{l}\text { Irrigation } 1 \\
\text { Irrigation } 2 \\
\text { Irrigation } 3\end{array}$ & $\begin{array}{l}3.46 \\
3.93 \\
4.10\end{array}$ & $\begin{array}{l}0.573 \\
0.491 \\
0496\end{array}$ & $\begin{array}{l}23.89 \\
28.43 \\
24.33\end{array}$ & $\begin{array}{l}3.66 \\
4.03 \\
4.20\end{array}$ & $\begin{array}{l}0.593 \\
0.501 \\
0505\end{array}$ & $\begin{array}{l}23.87 \\
28.42 \\
24.31\end{array}$ \\
\hline Bentonite 2 & $\begin{array}{l}\text { Irrigation } 1 \\
\text { Irrigation } 2 \\
\text { Irrigation } 3\end{array}$ & $\begin{array}{l}3.71 \\
4.25 \\
3.97\end{array}$ & $\begin{array}{l}0.511 \\
0.526 \\
0.473\end{array}$ & $\begin{array}{l}22.51 \\
27.10 \\
26.43\end{array}$ & $\begin{array}{l}3.81 \\
4.45 \\
4.07\end{array}$ & $\begin{array}{l}0.535 \\
0.545 \\
0.495\end{array}$ & $\begin{array}{l}23.33 \\
27.25 \\
26.40\end{array}$ \\
\hline Bentonite 3 & $\begin{array}{l}\text { Irrigation } 1 \\
\text { Irrigation } 2 \\
\text { Irrigation } 3 \\
\text { L.S.D. at } 0.05 \%\end{array}$ & $\begin{array}{l}3.42 \\
4.01 \\
4.08 \\
\text { n.s }\end{array}$ & $\begin{array}{l}0.611 \\
0455 \\
0.560 \\
0.10\end{array}$ & $\begin{array}{l}25.98 \\
27.13 \\
24.01 \\
\text { n.s }\end{array}$ & $\begin{array}{l}3.62 \\
4.31 \\
4.28 \\
\text { n.s }\end{array}$ & $\begin{array}{l}0.625 \\
0465 \\
0.570 \\
0.13\end{array}$ & $\begin{array}{l}25.96 \\
27.11 \\
23.99 \\
\text { n.s }\end{array}$ \\
\hline
\end{tabular}


Table 5. Effect of irrigation; bentoniet and cultivars and their interaction on Fe, $\mathrm{Mn}$ and $\mathrm{Zn}$ content of seeds during the two seasons of study.

\begin{tabular}{|c|c|c|c|c|c|c|c|}
\hline \multicolumn{2}{|c|}{ Seasons } & \multicolumn{3}{|c|}{2013} & \multicolumn{3}{|c|}{2014} \\
\hline Treatments & Characteristics & $\begin{array}{l}\mathrm{Fe} \\
(\mathrm{ppm})\end{array}$ & $\begin{array}{l}\text { Mn } \\
(\mathrm{pm})\end{array}$ & $\begin{array}{l}\mathrm{Zn} \\
(\mathrm{ppm})\end{array}$ & $\begin{array}{l}\mathrm{Fe} \\
(\mathrm{ppm})\end{array}$ & $\begin{array}{l}\mathrm{Mn} \\
(\mathrm{pm})\end{array}$ & $\begin{array}{l}\mathrm{Zn} \\
(\mathrm{ppm})\end{array}$ \\
\hline . & $\begin{array}{l}\text { Level1 } \\
\text { Level } 2 \\
\text { Level } 3 \\
\text { L.S.D. at } 0.05 \%\end{array}$ & $\begin{array}{l}2.40 \\
2.47 \\
2.54 \\
\text { n.s }\end{array}$ & $\begin{array}{l}0.509 \\
0.467 \\
0.560 \\
\text { n.s }\end{array}$ & $\begin{array}{l}0.097 \\
0.126 \\
0.113 \\
\text { n.s }\end{array}$ & $\begin{array}{l}2.39 \\
2.46 \\
2.52 \\
\text { n.s }\end{array}$ & $\begin{array}{l}0.497 \\
0.451 \\
0.548 \\
0.10\end{array}$ & $\begin{array}{l}0.833 \\
0.110 \\
0.098 \\
0.02\end{array}$ \\
\hline 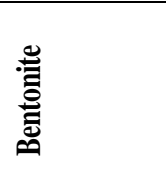 & $\begin{array}{l}\text { Level1 } \\
\text { Level } 2 \\
\text { Level } 3 \\
\text { L.S.D. at } 0.05 \%\end{array}$ & $\begin{array}{l}2.34 \\
2.52 \\
2.53 \\
\text { n.s }\end{array}$ & $\begin{array}{l}0.518 \\
0.521 \\
0.497 \\
\text { n.s }\end{array}$ & $\begin{array}{l}0.110 \\
0.113 \\
0.113 \\
\text { n.s }\end{array}$ & $\begin{array}{l}2.33 \\
2.51 \\
2.53 \\
\text { n.s }\end{array}$ & $\begin{array}{l}0.503 \\
0.511 \\
0.482 \\
\text { n.s }\end{array}$ & $\begin{array}{l}0.095 \\
0.098 \\
0.098 \\
\text { n.s }\end{array}$ \\
\hline 兽 & $\begin{array}{l}\text { Kareem } 14 \\
\text { Kareem } 7 \\
\text { Kafr El-sheikh } \\
\text { L.S.D. at 0.05\% }\end{array}$ & $\begin{array}{l}2.25 \\
2.37 \\
2.79 \\
\text { n.s }\end{array}$ & $\begin{array}{l}0.481 \\
0.422 \\
0.633 \\
0.09\end{array}$ & $\begin{array}{l}0.113 \\
0.115 \\
0.108 \\
\text { n.s }\end{array}$ & $\begin{array}{l}2.23 \\
2.36 \\
2.78 \\
n . S\end{array}$ & $\begin{array}{l}0.465 \mathrm{~B} \\
0.409 \\
0.622 \\
2.77\end{array}$ & $\begin{array}{l}0.098 \\
0.100 \\
0.093 \\
\text { n.s }\end{array}$ \\
\hline Bentonite 1 & $\begin{array}{l}\text { Kareem } 14 \\
\text { Kareem } 7 \\
\text { Kafr El-sheikh }\end{array}$ & $\begin{array}{l}2.118 \\
2.370 \\
2.556\end{array}$ & $\begin{array}{l}0.510 \\
0.408 \\
0.636\end{array}$ & $\begin{array}{l}0.105 \\
0.116 \\
0.110\end{array}$ & $\begin{array}{l}2.106 \\
2.358 \\
2.545\end{array}$ & $\begin{array}{l}0.491 \\
0.396 \\
0.621\end{array}$ & $\begin{array}{l}0.088 \\
0.103 \\
0.095 \\
\end{array}$ \\
\hline Bentonite 2 & $\begin{array}{l}\text { Kareem } 14 \\
\text { Kareem } 7 \\
\text { Kafr El-sheikh }\end{array}$ & $\begin{array}{l}1.936 \\
2.716 \\
2.935 \\
\end{array}$ & $\begin{array}{l}0.455 \\
0.420 \\
0.690\end{array}$ & $\begin{array}{l}0.121 \\
0.116 \\
0.103\end{array}$ & $\begin{array}{l}1.925 \\
2.701 \\
2.930\end{array}$ & $\begin{array}{l}0.441 \\
0.406 \\
0.686\end{array}$ & $\begin{array}{l}0.108 \\
0.100 \\
0.088\end{array}$ \\
\hline Bentonite 3 & $\begin{array}{l}\text { Kareem } 14 \\
\text { Kareem } 7 \\
\text { Kafr El-sheikh } \\
\text { L.S.D. at 0.05\% } \\
\end{array}$ & $\begin{array}{l}2.695 \\
2.043 \\
2.880 \\
0.980 \\
\end{array}$ & $\begin{array}{l}0.478 \\
0.438 \\
0.575 \\
0.17 \\
\end{array}$ & $\begin{array}{l}0.113 \\
0.113 \\
0.113 \\
\text { n.s } \\
\end{array}$ & $\begin{array}{l}2.685 \\
2.043 \\
2.865 \\
0.98 \\
\end{array}$ & $\begin{array}{l}0.463 \\
0.425 \\
0.560 \\
0.17\end{array}$ & $\begin{array}{l}0.098 \\
0.098 \\
0.098 \\
\text { n.s }\end{array}$ \\
\hline Irrigation 1 & $\begin{array}{l}\text { Kareem } 14 \\
\text { Kareem } 7 \\
\text { Kafr El-sheikh }\end{array}$ & $\begin{array}{l}1.948 \\
2.338 \\
2.918 \\
\end{array}$ & $\begin{array}{l}0.453 \\
0.461 \\
0.613 \\
\end{array}$ & $\begin{array}{l}0.093 \\
0.083 \\
0.115 \\
\end{array}$ & $\begin{array}{l}1.938 \\
2.328 \\
2.910 \\
\end{array}$ & $\begin{array}{l}0.436 \\
0.450 \\
0.605 \\
\end{array}$ & $\begin{array}{l}0.081 \\
0.070 \\
0.098 \\
\end{array}$ \\
\hline Irrigation 2 & $\begin{array}{l}\text { Kareem } 14 \\
\text { Kareem } 7 \\
\text { Kafr El-sheikh }\end{array}$ & $\begin{array}{l}2.246 \\
2.226 \\
2.951 \\
\end{array}$ & $\begin{array}{l}0.486 \\
0.276 \\
0.640 \\
\end{array}$ & $\begin{array}{l}0.135 \\
0143 \\
0.101 \\
\end{array}$ & $\begin{array}{l}2.235 \\
2.220 \\
2.940 \\
\end{array}$ & $\begin{array}{l}0.470 \\
0.263 \\
0.621 \\
\end{array}$ & $\begin{array}{l}0.118 \\
0.125 \\
0.088 \\
\end{array}$ \\
\hline Irrigation 3 & $\begin{array}{l}\text { Kareem } 14 \\
\text { Kareem } 7 \\
\text { Kafr El-sheikh } \\
\text { L.S.D. at 0.05\% }\end{array}$ & $\begin{array}{c}2.555 \\
2.565 \\
2.501 \\
1.00\end{array}$ & $\begin{array}{l}0.503 \\
0.528 \\
0.648 \\
0.16\end{array}$ & $\begin{array}{l}0.111 \\
0.120 \\
0.110 \\
0.03\end{array}$ & $\begin{array}{l}2.543 \\
2.555 \\
2.90 \\
1.00\end{array}$ & $\begin{array}{l}0.490 \\
0.515 \\
0.641 \\
0.16\end{array}$ & $\begin{array}{l}0.095 \\
0.106 \\
0.095 \\
0.03\end{array}$ \\
\hline Bentoniet1 & $\begin{array}{l}\text { Irrigation } 1 \\
\text { Irrigation } 2 \\
\text { Irrigation } 3 \\
\end{array}$ & $\begin{array}{l}2.383 \\
2.215 \\
2.446 \\
\end{array}$ & $\begin{array}{l}0.475 \\
0.493 \\
0.586 \\
\end{array}$ & $\begin{array}{l}0.090 \\
0.131 \\
0.110 \\
\end{array}$ & $\begin{array}{l}2.371 \\
2.205 \\
2.433 \\
\end{array}$ & $\begin{array}{l}0.460 \\
0.475 \\
0.575 \\
\end{array}$ & $\begin{array}{l}0.078 \\
0111 \\
0.096 \\
\end{array}$ \\
\hline Bentoniet2 & $\begin{array}{l}\text { Irrigation } 1 \\
\text { Irrigation } 2 \\
\text { Irrigation } 3 \\
\end{array}$ & $\begin{array}{l}2.651 \\
2.468 \\
2.468 \\
\end{array}$ & $\begin{array}{l}0.545 \\
0.478 \\
0.541 \\
\end{array}$ & $\begin{array}{l}0.101 \\
0.121 \\
0118 \\
\end{array}$ & $\begin{array}{l}2.643 \\
2.455 \\
2.458 \\
\end{array}$ & $\begin{array}{l}0.536 \\
0.465 \\
0.533 \\
\end{array}$ & $\begin{array}{l}0.086 \\
0.108 \\
0.101 \\
\end{array}$ \\
\hline Bentoniet3 & $\begin{array}{l}\text { Irrigation } 1 \\
\text { Irrigation } 2 \\
\text { Irrigation } 3 \\
\text { L.S.D. at } 0.05 \%\end{array}$ & $\begin{array}{l}2.170 \\
2.741 \\
2.706 \\
\text { n.s }\end{array}$ & $\begin{array}{l}0.508 \\
0.431 \\
0.551 \\
\text { n.s }\end{array}$ & $\begin{array}{l}0.100 \\
0.126 \\
0.113 \\
0.04\end{array}$ & $\begin{array}{l}2.161 \\
2.735 \\
2.696 \\
\text { n.s }\end{array}$ & $\begin{array}{l}0.495 \\
0.415 \\
0.538 \\
\text { n.s }\end{array}$ & $\begin{array}{l}0.085 \\
0.111 \\
0.098 \\
\text { n.s }\end{array}$ \\
\hline
\end{tabular}




\section{4- Water use efficiency:-}

Figure 1 show the effect of irrigation levels on seed yield of cowpea during both seasons of study.

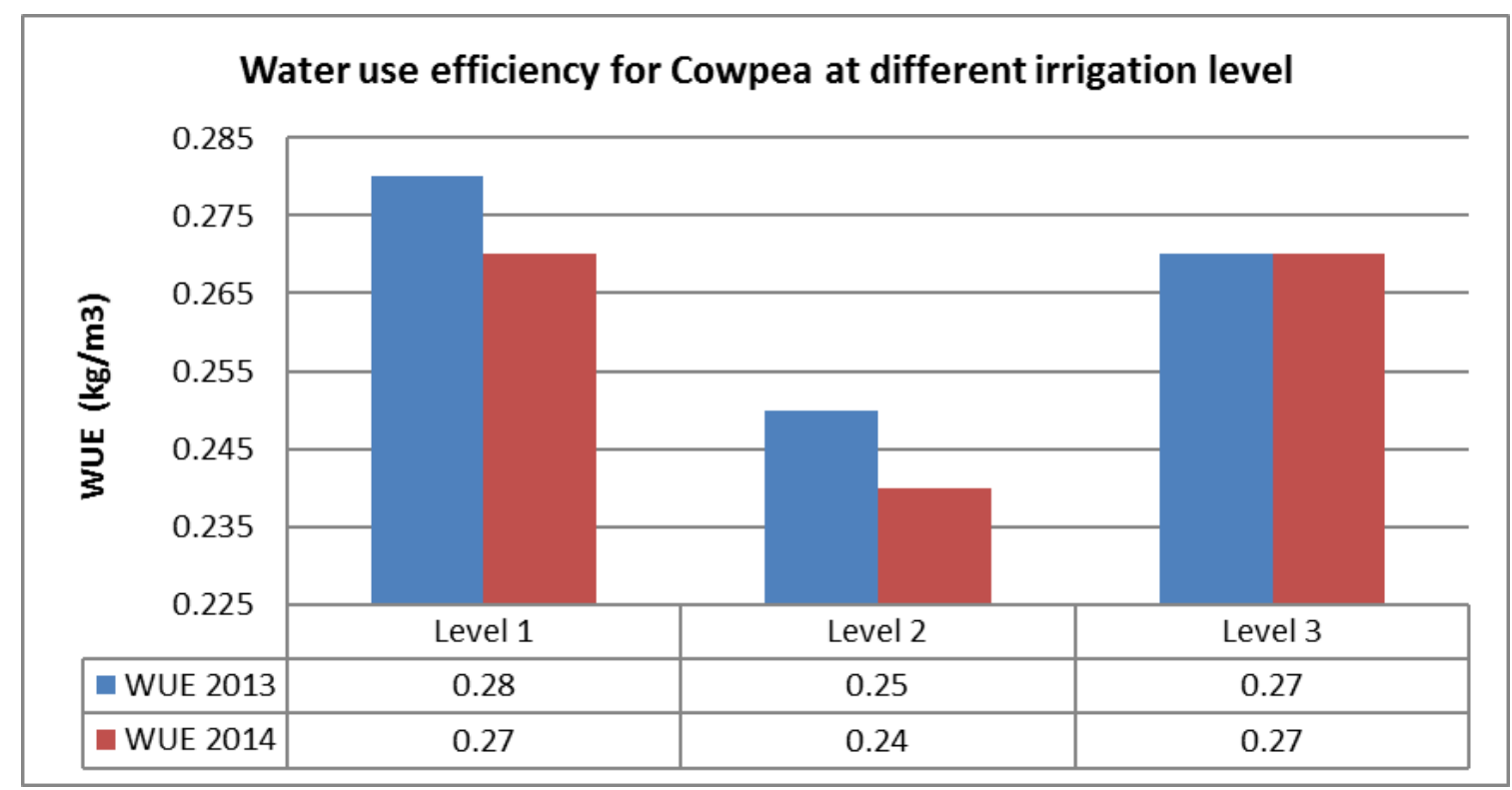

Figure 1 show that, the WUE values were varied from 0.25 to $0.28 \mathrm{~kg} / \mathrm{m}^{-3}$ in 2013 and from 0.24 to $0.27 \mathrm{~kg} / \mathrm{m}^{-3}$ in 2014 . The highest values of WUE increased with water shortage till level1 $(60 \% \mathrm{ETc})$ which was $0.28 \mathrm{~kg} / \mathrm{m}^{3}$ during season 2013 , while the lowest values of WUE achieved under irrigation level $2\left(80 \%\right.$ ETc) it was $0.24 \mathrm{~kg} / \mathrm{m}^{3}$ during season 2014. This result may be due to decrease of water added in season 2013 when comparing with season

2014. Also, level 1 during season 2014 and level 3 (100 ETc) during both seasons 2013 and 2014 recorded the same value of WUE $\left(0.27 \mathrm{~kg} / \mathrm{m}^{3}\right)$. It can be concluded that, under the conditions of this study, there was non positive impact of water shortages on WUE except for irrigation level $2(80 \%$ ETc) that was achieve the lowest values of WUE during both season 2013 and 2014.

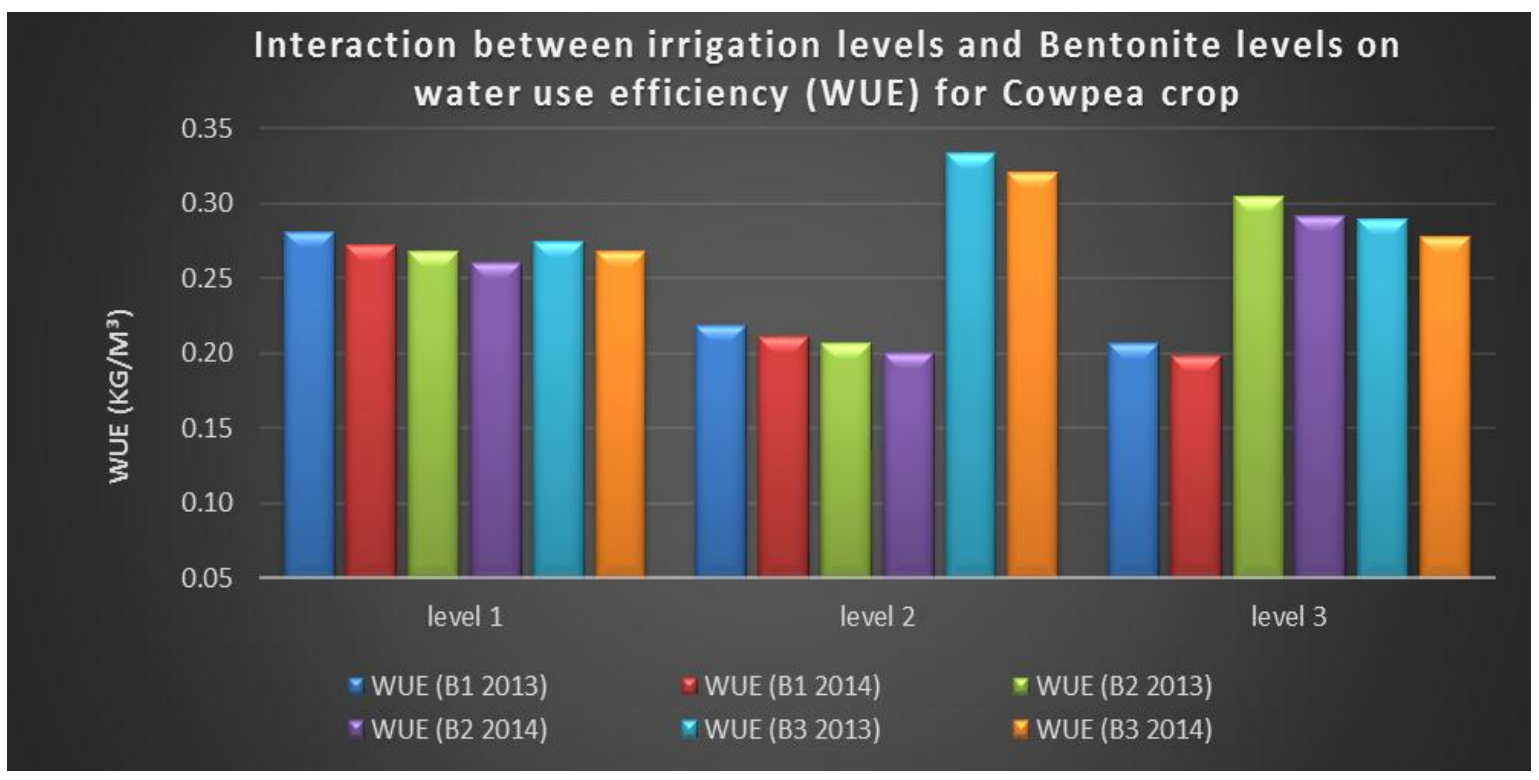

Figure 2 show that, the interaction between irrigation and bentonite levels on water use efficiency (WUE) for cowpea crop during season 2013 and 2014. It can be noted that the irrigation level 2 (80\% ETc) and bentonite level 3 (12 ton/fed.) gave the highest values of WUE $\left(0.33\right.$ and $\left.0.32 \mathrm{~kg} / \mathrm{m}^{3}\right)$ during seasons 2013 and 2014, respectively. Conversely, the interaction between irrigation level 3 and level 2 (100\% and 80\% ETc) and bentonite level 1 and level 2 (0 and 6 ton/fed.) were the lowest value of WUE $\left(0.20 \mathrm{~kg} / \mathrm{m}^{3}\right)$ during season 2014. Accordingly, there was positive relationship between the amount of added water shortages and increasing the amount of natural additions (bentonite), which led to the significant increase in WUE 


\section{References}

Ahmed, F.E. and Abd ElShakoor, H. 2010 .Effect of water stress applied at different stages of growth on seed yield and water-use efficiency of Cowpea AGRICULTURE AND BIOLOGY JOURNAL OF NORTH AMERICA ISSN Print: 2151-7517,

ISSN Online: 2151-7525, Science $\mathrm{Hu} \beta$, http://www.scihub.org/ABJNA

Allen, R.G., L.S. Pereira, D. Raes, and M. Smith. 1998. Crop evapotranspiration-Guidelines for computing water requirements. FAO irrigation and drainage paper No 56. Food and Agriculture Organization of the United Nations, Rome, Italy.

Abayomi, Y. A. And T. O. Abidoye. 2009 Evaluation of cowpea genotypes for soil moisture stress tolerance under screen house conditions. African Journal of Plant Science . 3 (10) : 229-237.

Aboamera, M.A.2010. Response of cowpea to water deficit under semi portable sprinkler irrigation system . Misr J. Ag. Eng., 27 (1): 170- 190.

Balba, A.M.(1999) Soils, Water and Development in Arab Countries .Monshaet El-Maaerf Publ. Co. alex., Egypt .

Benkhelifa, M. ; M. Belkhodje ; Y. Daoud and D. Tessier (2008) Effect of maghnian bentonite on physical properties of sandy soils under semi arid Mediterranean climate . Pak. J. Biol. Sci. 11, 17.

Black, C.A. (1965).Methods of soil analysis.Part 1 and 2. Amer. Soc. Of Agronomy. Madison, Wisconsin.

Cotienie, L.; Verloo, M.; Kiekens. L.; Velghe, G, and Camerlyck, R.

(1982): Chemical analysis of plants and soils in Laboratory of Analytical and Geochemistry. Slate Univ., Ghent. Belguium, 33-111.

Dadson, R. B. , F. M. Hashem, I. Javaid, J. Joshi, A. L. Allen, and T. E. Devine . 2005. Effect of water stress on the yield of cowpea(Vigna unguiculata L. Walp.) genotypes in the Delmarva Region of the United States . J. Agronomy \& Crop Science 191, 210-217.

Doorenbos, J., and A.H. Kassam. 1979. Yield response to water. FAO Irrigation and Drainage Paper No. 33. Food and Agriculture

Organization of the United Nations, Rome, Italy.

El-Sisi, S.M.1996. Use of (tafla) bentonite for improving soils of Beni- Suef Governorate . M.Sc. Thesis Fac.Of Agric. Ain Shams Univ.

Faloye, O. T. and M. O. Alatise .2015 .Effect of varying water applications on evapotranspiration and yield of cowpea under sprinkler irrigation system. International Journal of Agriculture

and Crop Sciences. Available online at www.ijagcs.com IJACS/2015/8-3/307-319 ISSN 2227-670X (C2015 IJACS Journal.

FAO. FAOSTAT3,2013 . Agriculture Rome, 2015. Available in: http://faostat3.fao.org/fao stat /collections? Subset=agriculture. Accessed at: June. 96, (9) : 1275-1284.

Gzaban ,J.; G. Siebielec ; E. Czyz and J. Niedzwieck (2013): Effect of bentonite addition on sandy soil chemistry in a long -term plot Experiment (1); effect on organic carbon and total nitrogen . Pol. J. Environ. stud., 22(6): 1661- 1667.

Hussaini , M. A. , M. K. Othman , M.F. Ishyaku and A.M. Falaki. 2004 .Response of cowpea (Vigna unguiculata L. Walp) to methods and levels of irrigation under varying fertilizer levels in a semi-arid region of Nigeria. Journal of Food, Agriculture \& Environment 2 (3\&4) : 137-140.

Ichi, J.O. , M.Sc. ; H.E. Igbadun,; S. Miko and A.M. Samndi. 2013. Growth and Yield response of selected cowpea (Vigna unguiculata (L.)Walp) varieties to irrigation interval and sowing date. The Pacific Journal of Science and Technology http://www.akamaiuniversity.us/PJST.htm 14(1) May.

Lovelli, S., M. Perniola, A. Ferrara, and T. Di Tommaso. 2007. Yield response factor to water (Ky) and water use efficiency of Carthamust inctorius L and Solanum melongena L. Agric. Water Manage. 92, 73-80.

Odion, E.C., O.E. Asiribo, V.B. Ogunlela, B.B. Singh, and S.A. Tarawali. 2007. Strategies to improve and sustain food production capacity in the savanna: The role of leguminous fodder crops in maintaining soil fertility and health. J. Food Agri. Environment. 5:338-344.

Piper, C.S. (1950): Soil and plant analysis, Inter. Science, Publishers.INC, New York, USA . SAS, 2003. Statistical Analysis System SAS Users Guide : Statistics .SAS Institute Inc. Editors, Cary, NC.

Shalabey, O.E.; Araf, M.M. 'and Bayourai, N.A. 2005 .Utilization of some soil amendments a sources of micronutrients in soil and their effect on yield of cowpea plants (Vigna unguiculataL.)in newly reclaimed soil .Annals Of Agric. Sc., Moshtohor, 43(3): 1357-1373. 


\title{
تأثير كفاءة استخدام المياة ومستويات البنتونيت علي النمو الخضري ،المحصول والتركيب الكيماوي لبذور اللوبيا النامية في الاراضي الرملية
}

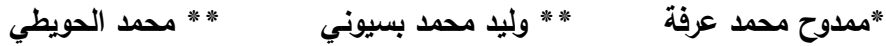

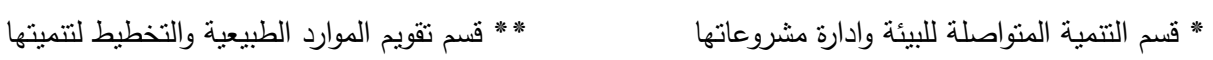 \\ معهز الدراسات والبحوث البيئية - جامعة مدينة السادات- مصر • لمورد
}

أجريت تجربتان حقليتان في مزرعة معهد الدراسات والبحوث البيئية - جامعة مدينة السادات خلال موسمي 2013 و 2014 لدراسة تأثير ثلاث مستويات من الري و خام البنتونيت علي ثلاثة أصناف من اللوبيا ( كفر الثيخ ، كريم 7 ، كريم 14 )ونم استخدام طريقة الري بالتنقيط والري بثلاثة

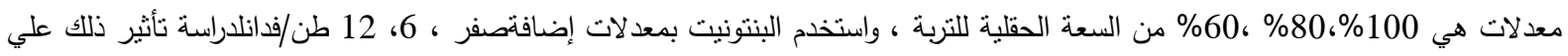
النمو الخضري متمثلا في طول النبات ، عدد الأفرع لكل نبات والوزن الطازج للنبات ، المحصول ومكوناته متمثنا في وزن 100 بذرة ، محصول

النبات بالجرام ومحصول الفدان من البذور بالكيلوجرام ومحتوي البذورمن عناصر النبتروجين، الفوسفور ،البوتاسيوم، الحديد، المنجنيزو الزنك.

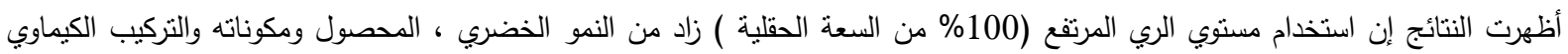

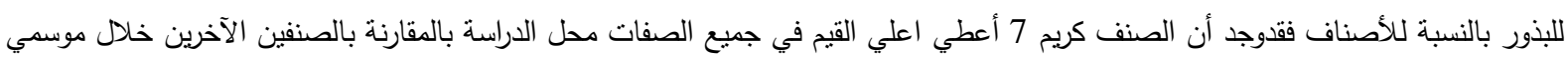

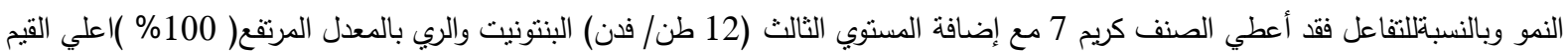
للصفات محل الدراسة . للصفات بصفة عامة توصي الدراسة بزراعة اللوبيا صنف كريم 7 مع إضافة البنتونيت بمعدل 12طن للفدان و الري بمعدل ري 100\% من السعة الحقلية للتربة للحصول علي اعلي نمو خضري ومحصول ومكوناته وكذللك زيادة محتوي بعض العناصر الكبري والصغرى الضرورية في البذور • 